\title{
AL BENIGNO LETTORE
}

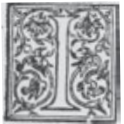

[1] 1 fare passaggio per questo mondo senza imprimervi vestigio alcuno, è comunemente stimato vano viaggio et inutile tracorso. E Salomone nelli Proverbii fra li quattro che nel camino non producono di loro segnale, fu annoverato il serpente, che sopra duro sasso si striscia, animale non solamente improficuo, ma oltre modo al nostro genere nocivo ed inimico.

Sono stato ancor io dalla natura chiamato a transitare questo sentiero mondano, per il che ho giudicato convenevole lasciarvi alcuna orma, che se poi in breve, come stimo, il calpestio d'altrui la deturbi, overo il tempo l'abolisca, poco di ciò mi curo, havendo il mio devere eseguito.

Il proponimento del presente impiego non è la difesa della scioperata, flatuosa ignoranza, che di sé tutto presume, e che a caso si regge, ma della modesta, discreta, e che non temerariamente si arroga quello che non ha, né tiene. Confuta Socrate il sapere humano, non l'inspirato et infuso da mente superiore, avanzandosi da tale divisamento che riconoscendosi la fiacchezza del natio nostro intendimento, si rendiamo flessibili alli sentimenti et attestationi delle sacrate lettere.

Né paia ad alcuno troppo ardita intrapresa ad homo della mia conditione, l'attentare la libertà dell'animo humano inviluppato da lacci, con quali l'ardito e troppo pretendente sapere lo tiene legato e [2] stret|to, poiché l'esopico topo, con il suo minuto rodimento, già sciolse generoso e feroce leone. E se nel principio dell'accademica institutione fu alla humana autorità sospesa et interdetta la sua rigorosa e despotica giuridittione, ciò non seguì per dispregio che si tiene verso il serio e pesante parere di più saggi, ma solamente per evitare quelli ciechi et inosservabili colpi che sogliono offendere e ferire coloro, che non oltre modo nelli libri versati sono; ritrovandosi piuttosto alquanto pronti d'ingegno, che carichi di allegationi e provisti di aliene dottrine, avertendo di più che tutto ciò che pronontiò Socrate, nella everssione dell'humano sapere, fu piuttosto per modo tentativo, septico, e dubbitativo, che dogmatico et assertivo.

Et infine scaturendo non poche scorrettioni, e fallacie nel corso dell'opera, si compiaccia il cortese lettore darle facile venia, e che rimangano amassate et indulte con tanti altri errori et illusioni, che alli esercitii e fontioni della humana mente quotidianamente incontrano et accadono, come che nel progresso dell'opera si dimostrarà. 


\section{TO THE BENIGN READER}

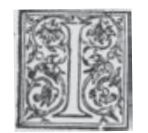

[1] $\mathrm{t}$ is commonly ${ }^{6}$ considered that to pass through this world without leaving any traces would be a vain and useless journey. And Solomon, [in his description] in Proverbs ${ }^{7}$ of the four things that do not leave any traces in their passage, includes the snake, which slithers over hard stones, an animal that is not only useless, but also extremely harmful and hostile to humankind.

Called by Nature to walk this mundane path, I deemed it appropriate to leave a trace on it, even though I believe that after a short while, the passage of others will spoil it or time will erase it. Nevertheless, I do not care much about this, because I will have done my duty.

The purpose of this work is not to defend a lazy and pretentious ignorance, which all presume [to know] and which is led by Chance, but a modest and discreet one, which does not recklessly claim that which does not belong to itself. Socrates confutes human knowledge, but not that [knowledge] which is inspired and instilled by a superior mind, and he comes to this consideration by acknowledging that the weakness of our innate understanding makes us pliant to the sentiments and testimonies of the Holy Scripture.

Furthermore, the attempt to release the human mind from the ropes in which it was entangled by arrogant and overly pretentious knowledge must not seem too daring an endeavour for a man of my status, [2] because Aesop's mouse managed to free the generous and ferocious lion with its mere gnawing. ${ }^{8}$ Furthermore, if at the beginning of the institution of the Academy, the strict and despotic jurisdiction of human authority was suspended and banned, this did not happen in order to disdain the serious and weighty opinions of wiser men, but rather simply to avoid those blind and unnoticeable blows which usually harm and injure those who are not only conversant with books, but also more endowed with a quick wit rather than burdened with bonds ${ }^{9}$ and provided with foreign doctrines. Moreover, they realised that everything Socrates said in order to subvert human knowledge was a sceptical and doubting attempt rather than dogmatic and assertive.

Lastly, I wish that the kind reader will forgive the many mistakes and fallacies appearing throughout the text and indulgently group them together with many other errors and illusions that the exercises and functions of the human mind encounter and undergo every day, as will be demonstrated during this work. 